\title{
Big Business and Cadre Management in China
}

\author{
KJELD ERIK BRØDSGAARD AND KASPER INGEMAN BECK
}

\begin{abstract}
Leading cadres in China are subject to rotation. An interesting form of rotation takes place between big business and the political world. That means one fifth of China's governors and vice governors have a business background as heads of one of China's large State-Owned Enterprises (SOEs). How this takes place and which qualifications the involved business leaders possess are shrouded in mystery. Based on prosopographical studies of Chinese business leaders who have participated in the Chinese Executive Leadership Program (CELP), this article attempts to open the black box. The study examines the career pathways of CELP participants in Party, government and business positions. The study shows that 84 of the 261 CELP SOE participants (2005-2018) were subsequently promoted, and 20 of these promotions were from SOEs to leading Party and government positions. In some cases, former business leaders became Party secretaries in important provinces or ministers in key ministries. The article also argues that Chinese business leaders have managed to keep their administrative ranking in the Chinese nomenklatura system. In fact, Chinese business leaders are quasi officials (zhun guan) and form an important recruitment base for leadership renewal. As such, the article suggests that the rotation of cadres within the 'Iron Triangle' of Party-government-business constitutes the main unifying and stabilising factor in the Chinese political system.
\end{abstract}

Keywords: Chinese Communist Party (CCP); elite politics; state-owned enterprises; government-business relations; nomenklatura; government officials

\section{Introduction: Party and Cadre Management}

With 95 million members, the Chinese Communist Party (CCP) is the world's largest political party. The CCP is present in all corners of Chinese society, be it government offices at central and local level, rural villages, urban neighbourhoods, state-owned enterprises (SOE), privately-owned companies, even joint ventures and NGOs. ${ }^{1}$ However, the CCP does not rule China directly, but through the cadre corps.

The definition of a cadre has varied over time. Lenin and the Soviet

This article can be accessed at https:/ / doi.org/10.22439/ cjas.v39i2.6399. 
Communist Party originally defined cadres as the vanguard of the revolutionary class, who should act as the nucleus of the Communist movement and were expected to devote their whole life to the revolution (Lenin 1973). After the 1949 revolution, the term cadre usually referred to people who assumed leadership positions within an organisation or who assumed responsibility for a specific political task. During the 1950s, the concept lost most of its revolutionary connotations and instead, cadres were defined by bureaucratic and occupational distinctions, including administrative personnel, technicians, news and publishing personnel, teaching personnel and personnel in culture and arts. Cadres were also closely linked to an internal ranking system with an important distinction between ordinary cadres and leading cadres (lingdao ganbu). Leading cadres were ranked at division (county level) and above.

Civil servants (gongwuyuan) form the core group of the cadre corps and constitute the backbone of the Party and state administrative system. During the Mao era, China did not have a civil service system, but during the 1980s, Deng Xiaoping on several occasions suggested separating the Party and government in order to reform the governing system (Deng 1983: 280-302; FBIS 1986). The Tiananmen debacle put a temporary end to such discussion, but in 1992, the political situation had stabilised, and the civil service reform was formally introduced (NPC 1993). It was based on a ranking system with corresponding salary differences and benefits. Currently there are 27 ranks from office worker to president and prime minister. Civil servants in leading positions are normally Party members and part of the nomenklatura system (Brødsgaard 2012a; Burns 1994). ${ }^{2}$

There is some information available concerning the number and composition of the civil servant corps. By 2016, there were 14 million civil servants staffing government and Party administration from the central to local level, i.e., from the national level to the township level (NBS 2018). To be a civil servant is associated with high prestige in China, and there are hundreds of thousands of hopeful candidates competing for the few positions available.

Public service units (shiye danwei) also form an important part of the public sector in China. They include hospitals, schools, universities and other institutions in health care, sports, social welfare, culture and research. There are about twice as many employed in shiye danwei than in the civil service system. Often employees in shiye danwei will have salaries and benefits similar to civil servants.

SOEs form the third sector in the Chinese public sector. There are 30.5 
million employees in SOEs reporting in the State-owned Assets and Supervision Commission (SASAC) system (SASAC 2017). The most important SOEs - the so-called centrally managed enterprises (zhongyang qiye) - employ 13.6 million employees. These enterprises are managed by the central SASAC, which is a ministerial-level organisation controlling the top SOEs on behalf of the State Council. ${ }^{3}$ They are also called China's national champions and were established as an attempt to create big companies that can compete with the large western multinational companies. There were originally 196 of these national champions, but as a result of a program of mergers and acquisitions, there are now only 96 centrally managed enterprises. These are huge enterprises in terms of employment and revenues. Most of them are on the global Fortune 500 list of the world's largest enterprises. They are, in general, larger than privately-owned companies such as Huawei, Alibaba and Tencent.

There are also 18 SOE banking and insurance groups in the stateowned sector of the economy. They are controlled by the Central Huijin Investment Corporation, which functions in the same way as SASAC. These institutions include a number of big commercial banks such as Bank of China, Industrial and Commercial Bank of China, Agricultural Bank of China, Bank of Communication, China Construction Bank, China Merchants Bank, as well as a number of policy banks such as China Development Bank, Export-Import Bank of China and Agricultural Development Bank.

The most important of the centrally managed enterprises are the socalled nomenklatura companies. These are the companies where the top leadership, board chairman, president/general manager is managed by the Party's Central Organisation Department rather than the SASAC. This is because the leaders of these 46 companies are on the central nomenklatura list. Another interesting aspect is that the leaders of these companies are administratively ranked. This is the case even though several Party documents have announced that administrative ranking for SOE executives should be abolished. Due to their administrative ranking, Chinese SOEs' executives have been called semi-officials (zhun guan) (Yang, Yang and Nie 2013). The large financial institutions are also part of the nomenklatura systems, and their top executives are likewise appointed on the recommendation of the Central Organisation Department. These executives are also ranked at vice-ministerial level.

Chinese business leaders exercise political influence. In 2002, for the first time, they appeared as a distinct group in the elite central committee 
alongside representatives from the central government and Party institutions, provincial Party and state administrations and the military. 18 corporate leaders were elected to the 16 th central committee, including two full members and 16 alternate members. In 2012, at the 18th Party congress, the representation of business leaders in the central committee was strengthened significantly. The number of representatives from the centrally managed companies declined by one to 17 , but the number of full members increased from one to six. At the recent 18th Party Congress, the representation of SASAC companies in the Central Committee fell to 11 alternate members. The reduction of business executives in the Central Committee was related to the continuance of the anti-corruption campaign initiated by Xi Jinping in 2012. The campaign has targeted a number of business executives, especially in the oil sector (Zhang, Zhang and Liu 2017).

An additional measurement of the political influence of Chinese business leaders is the number of ministers and provincial leaders with a business background. Currently, 49 of China's 293 provincial Party secretaries, governors and vice governors have a business background. The same is the case for five out of China's 29 ministers.

In this article, we will investigate the cadre rotation and promotion system further with a particular focus on SOE leaders and their rotation to Party or government jobs. After a short introduction to the cadre rotation system, the article analyses data from the China Executive Leadership Program (CELP). CELP is a training course for Chinese business executives from China's centrally managed enterprises organised by Cambridge University and the Copenhagen Business School. CELP is a window into an otherwise closed system and provides us with plentiful examples that illustrate the mechanism of the cadre rotation system. The article finishes with a general discussion of Chinese (super) managers and their political connections.

\section{Cadre Rotation}

An important part of cadre management is the cadre rotation system. For leading cadres, the rule is that they are transferred or rotated after their second term, i.e., after ten years in office. Either they will be transferred to a higher-level position, or they will stay at the same rank, but without leadership responsibility. The Party's organisational department at the various levels manages the system. At the national level, it is managed by the Central Organisation Depart- 
ment, which keeps the files of all leadership positions at vice-ministerial level and above and prepares recommendations for leadership appointments.

Rotation often takes place between Party positions and government positions. This is, for example, the case when a minister or a governor is transferred to a position as provincial Party secretary. Although these positions are all at the ministerial level, such transfers are normally regarded as a promotion since Party positions outrank government positions.

Chinese big business is also part of the cadre rotation system. Executives in the largest centrally managed nomenklatura companies are part of the nomenklatura system and therefore also subject to rotation. The interesting thing is that this not only takes place within companies, so that a business executive may be transferred to head another, perhaps, rival company; it also takes place between business and Party, and business and government and vice versa (Brødsgaard 2012b; Leutert 2018). The most prominent example is the case of Zhou Yongkang.

In the 1990s, Zhou Yongkang was head of China's largest oil company, China National Petroleum Corporation (CNPC). In 1998, he was transferred to government work to become minister of Land and Resources. Two years later, he was transferred to Party work and appointed Party secretary of Sichuan province. He held this position until 2002, when he returned to the central government as minister of Public Security. In 2007 at the 17th Party congress, he was appointed member of the Standing Committee of the CCP Politburo in order to head the powerful political-legal security system in China.

There are many other examples. They are important as they show the close link between Party, government and big business in China. These links form an iron triangle, which is at the heart of the Chinese political power system.

\section{Promotion}

It is unclear which factors determine an individual's chances of promotion. Some scholars argue that promotion is based on economic performance (Li and Zhou 2005); other scholars maintain that political connections are decisive (Shih, Adolph and Mingxing 2012; Chen 2006). A third group holds that economic performance matters more at the lower levels, whereas political connections are more important at the central level (Landry, Lü and Duan 2014). This paper posits 
that management skills are important and have been overlooked in the literature.

Chinese cadres are all required to attend regular training and education in issues pertaining to ideology and management skills. This mainly takes place in one of China's many Party schools. There are around 2500 of these, but the most important is the Central Party School in Beijing, which is normally headed by a member of the Standing Committee. ${ }^{4}$ Leaders at vice-ministerial level and above are regularly trained at this school. Other important training institutions include the cadre academies in Jinggangshan, Pudong and Shanghai (on leadership training in China see Pieke 2009 and Lee 2015).

However, Party regulations allow government and business leaders at the director-general level and vice-ministerial level to attend training courses abroad. For a number of years, the Kennedy School at Harvard University organised training seminars for high-level Chinese government officials. In a similar way, Cambridge University and the Copenhagen Business School have cooperated to organise training courses for Chinese business executives from China's centrally managed enterprises. Each year since 2005, around 25 business leaders have attended the China Executive Leadership Program (CELP), which is a four-week course focused on lectures and discussion on key issues pertaining to international business, public management reform, environment and climate, business management, etc. Over the years, a total of 261 business executives have taken part in CELP. Prominent scholars and board chairmen and CEOs from large western multinational enterprises lecture in the course, and the participants also have meetings with government ministers in the UK and Denmark. It is interesting to investigate whether participation in the CELP training course had any impact on the careers of those who attended the program. Many of the participants have subsequently been transferred to positions in the Party and government, while others have been promoted to positions in other (competing) SOEs. As such, the CELP is a window into an otherwise closed system and provides us with plentiful examples that illustrate the mechanism of the cadre rotation system.

\section{Analysis of CELP Data}

The following discussion is based on a dataset covering the period 2005-2019 with information on career movements among 359 participants in the CELP. There is no data in the year 2008 as the program 
was cancelled this year due to the Wenchuan earthquake. In 2020, the program was cancelled due to the Covid-19 pandemic. During all the years of the program, 261 of the 359 CELP participants were SOE leaders with the remaining being government and Party officials (e.g., from SASAC, State Development Research Centre and Central Organisation Department). The group of 261 SOE leaders in the CELP are most important for the investigation in this article. The CELP group of SOE leaders is not representative of the whole population of Chinese SOE leaders, since they represent an elite group especially selected for foreign training programs by the Central Organisation Department of the CCP. However, the group is arguably representative of the top layer of SOE leaders in China, and the data presented here, therefore, does provide evidence on the career dynamics of elite SOE leaders in China (rather than on all state sector leaders in China). The 261 SOE leaders came from different industries (see Figure 1); banking/finance and oil/gas/electricity sectors made up a large part of the CELP SOE participants. A large group of officials also came from automobile production and transport (aviation) industries.

Figure 1: Distribution of CELP SOE participants across industries (2005-2019)

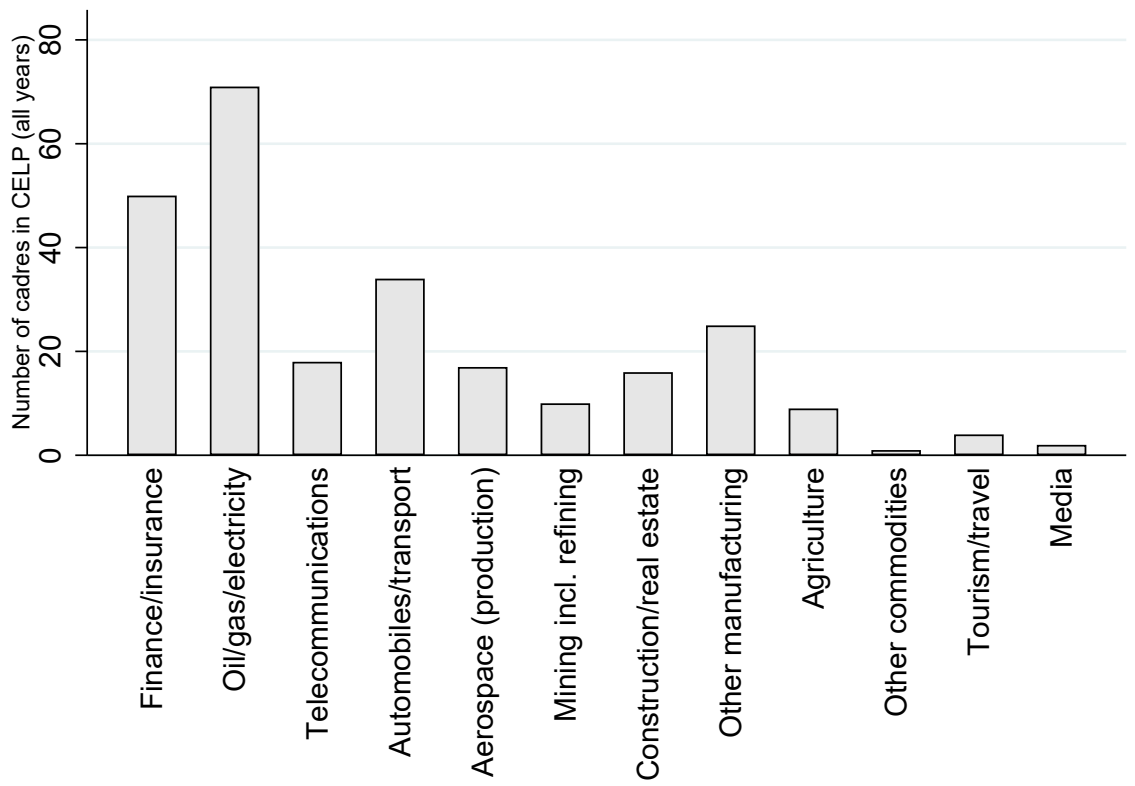

Data based on 261 SOE leaders participating in the CELP program (2005-2019). Participating government and Party officials are excluded in Figure 1. Transport includes the aviation industry. 
Overall, 108 or 30 per cent of the 359 participants in CELP have been promoted subsequent to taking part in the program. Among the SOE leaders in the CELP program, 84 participants, or 32 per cent of the 261 participants, have been promoted after participating in CELP. In terms of transfers from business to Party and government positions, 20 or 23.8 per cent of the promoted participants have made this move, while 76.2 per cent stayed in the business sector (see also Appendix 1 for a list of the 20 SOE leaders who have been moved to government or Party positions). These facts testify that the Central Organisation Department in charge of promotions of the top layer of cadres attach significant importance to managerial skill and on-the-ground business experience when selecting future political leaders in China. The relatively high number of political promotions among the CELP participants directly contradicts earlier findings by Leutert (2018), who concludes that transfers from SOEs to Party or government is a very rare event; Leutert documents that 23 of the 862 SOE cadres included in her study were moved to Party or government jobs in the period 2003-2012 (Leutert 2018: 16). The findings presented here, instead, suggest that such a move is common among top SOE leaders electable for participation in elite training programs, such as the CELP. It might also suggest that transfers from business to politics in China have become more common after 2012, where the data in Leutert's study ends.

Figure 2 shows the sectorial distribution of these promoted SOE officials; naturally, following the large number of cadres from banking/ finance and oil/gas/electricity sectors, these industries also make up the largest part of promoted SOE leaders. However, among the SOE leaders moving to a government/Party role after CELP participation, we also find a large number of leaders from the aerospace industry and 'other manufacturing' (e.g., includes computer, electronics and defence industries). It is possible that the sectorial distribution of the political promotion of business leaders reflects the strategic importance of these industries for the CCP. Surprisingly, no SOE leaders from the telecommunications sector have made this move.

Finally, Figure 3 shows the percentage of promoted SOE leaders from each CELP cohort, who have been promoted to a government or Party position. Looking at specific years, 40 per cent of the promoted SOE cadres from the 2006 cohort have been transferred to work in Party and government institutions (60 per cent have been promoted to other business positions). The 2006 cohort included current Party secretaries in Heilongjiang and Liaoning provinces, as well as the Minister of Industry and Information Technology (see Appendix 1). Other 
Figure 2: Distribution of promoted CELP participants across industries (2005-2018)

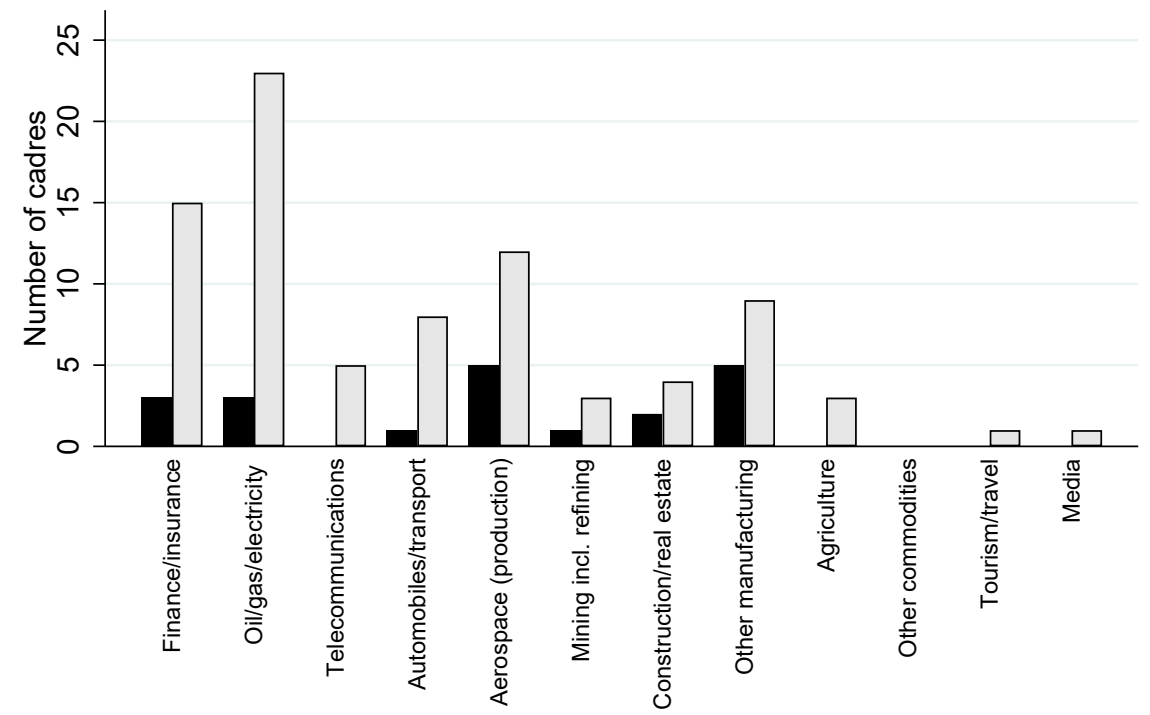

$$
\text { Promoted from SOE to Gov/Party } \square \text { Total promoted }
$$

'Other manufacturing' e.g., includes computer, electronics and defence industries. 'Other commodities' includes all non-metals e.g., chemicals and plastics.

Figure 3: Promotion of CELP participants from SOE to gov./Party positions (2005-2018)

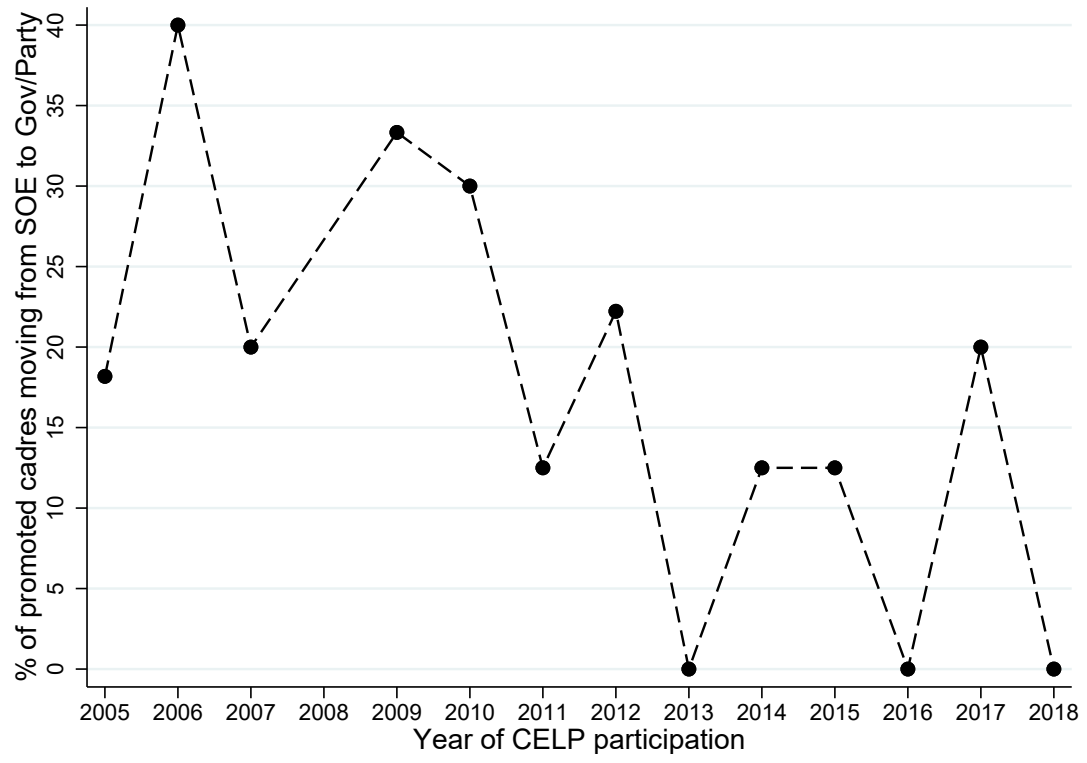


strong cohorts include 2009 and 2010, where 30-35 per cent of the promoted cadres were transferred to Party or government jobs. This includes current Party secretary of Zhejiang province, Yuan Jiajun. In other cohorts, namely 2013, 2016 and 2018, we are yet to see any political promotions of business leaders from the CELP program.

\section{Examples of cadre rotation among CELP leaders}

Appendix 1 contains a list of 20 cadres participating in CELP, who have been promoted from a SOE leadership position to important government or Party positions. In addition to the 20 SOE leaders in Appendix 1, it should be mentioned that a number of Party and government officials accompanying or leading the annual CELP delegation have also experienced important promotions. This includes Feng Fei, former director general in the Development Research Centre and current Party secretary of Hainan province, and Zhang Jinan, former vice minister in the Central Organisation Department and current minister of Ministry of Human Resources and Social Security. However, in this context we will focus on the rotation and transfer of business leaders.

The lists in Appendix 1 show that most business executives who are transferred to government and Party jobs experience a lateral transfer at the same administrative level. This implies that they are transferred from their executive position, which for nomenklatura companies is at a vice-ministerial level, to a position as vice governor, vice minister or deputy Party secretary, which is at the same administrative level. However, we see such transfers as promotion as they open a completely new career track, which often results in appointment to a ministerial-level position as governor, minister or Party secretary of a province and thereby provides an opportunity to postpone retirement until the age of 65 .

Below are short biographies of some of the more important examples of the career track of CELP business executives who have been transferred to government and Party positions. The first and probably most prominent example is Zhang Qingwei. He was general manager of China Aerospace Science and Technology Industry 2001-2007 and chief commander of the Lunar Exploration Program, Chang'e 1. Following his participation in the 2006 CELP program, he was appointed minister of the Commission of Science, Technology and Industry for National Defense in 2007. When the commission was merged with the Ministry of Industry and Information Technology in 2008 and renamed the State Administration for Science, Technology and Industry for National 
Defense (SASTIND), Zhang Qingwei was moved to become chairman of China Commercial Aircraft Co. (COMAC) and tasked with developing project C919, China's first homegrown passenger jet. In 2011, Zhang was transferred to Henan to become acting governor and from 2012, governor. In 2017, he was appointed Party secretary of Heilongiiang. He has been a full member of the Central Committee since 2002.

Ma Xingrui, who took part in the 2005 CELP program succeeded Zhang Qingwei as general manager of China Aerospace Science and Technology Corporation in 2007. In 2012, he was also appointed director of SASTIND, China National Space Administration (CNSA) and China National Atomic Energy Authority. In 2013, he was transferred to the central government to become vice minister of Science and Technology. After only two years, he was moved to Guangdong to serve as Party secretary of Shenzhen and from 2017, governor of Guangdong. He entered the Central Committee in 2012 and was re-elected in 2017.

Yuan Jiajun was senior vice president under Ma Xingrui and was a participant in CELP in 2010. In 1996, he became first deputy commander and from 2000, commander of the Shenzhou Spacecraft. From 2003, he was also president of Chinese Academy of Space Technology. He was also a leading figure in establishing the Beidou Satellite Navigation System. In 2013, he was moved to Qinghai to become executive vice chairman of the regional people's government. Just one year later, he was transferred to Zhejiang to become executive vice governor, and in 2017, he was promoted to governor of the province. In 2020, he was promoted again, this time to Party secretary of Zhejiang province. He was an alternate member of the 17th Central Committee and elected full Central Committee member at the 19th Party congress in October 2017. He is perhaps the most intriguing example of a successful business executive being transferred to political work.

Zhang Guoqing was part of the powerful 2006 cohort of CELP participants in his capacity as senior vice president of China North Industries Corporation. In October 2008, he was promoted to president and deputy Party secretary of the company. In April 2013, he was moved to Chongqing to serve as deputy Party secretary. In January 2017, he was promoted to mayor of Chongqing but was transferred to Tianjin in December 2017 to become mayor of the city. In September 2020, he was promoted to Party secretary of Liaoning province. He was elected full member of the 18th and 19th Central Committee.

Xiao Yaqing took part in the 2006 CELP program in his capacity of general manager and Party secretary of China Aluminium Corporation. 
In February 2009, he was transferred to the State Council to work as vice secretary general. In 2013, he was appointed deputy director of the State Council leading group for promoting medium and small enterprise development. In 2016, he was promoted to director and Party secretary of SASAC, and in August 2020, he was further promoted to minister of Industry and Information Technology. He was an alternate member of the 17th Central Committee and member of the 18th Central Disciplinary Commission. At the 19th Party congress in 2017, he was reappointed to the Central Committee, this time as a full member.

They are all prime examples of the rotation taking place in the iron triangle of Party-state-business. Their vast experiences in running large businesses and large-scale projects have proven useful to the regime and shows that the power system is able to coopt and integrate talent. This ability is one of the main reasons why the Party-led political system has maintained its vitality and is not about to collapse (for an opposing view, see Shambaugh 2016).

\section{Chinese Super Managers}

In his monumental work Capital in the Twenty-First Century, Thomas Piketty (2014) has a chapter on the phenomenon of super managers in large Western (in particular American) companies. He describes how these super managers draw salaries that sometimes are a hundred times larger than the average wage of the employees in their companies. However, China also has its super managers drawing salaries disproportionate to ordinary staff and workers in the companies they manage.

Surveys conducted during the $\mathrm{Hu}$ Jintao era of the salaries of leaders of central enterprises showed that in some instances, top management in central enterprises were paid annual salaries over 100 times more than ordinary employees (Sohu 2010). The report mentioned that when enterprise reform started, the salary gap between the highest-ranked manager and ordinary employees were only ten times. In 2002, it was regulated that it should not exceed 12 times. Yet CEO salaries continued to rise significantly compared to the salaries of ordinary workers. There were media reports which claimed that Fu Chengyu, at the time chairman of CNOOC, had an annual salary 12.05 million RMB. Mai Boliang, CEO of China International Marine Containers, ranked second with a yearly salary of 6.85 RMB on a list of salaries published by Ifeng finance (Sina 2009).

One year into Xi Jinping's ascension to power, Economic Science Press published a series of reports on executive remuneration in China's 
listed companies. They showed that the average executive remuneration among all of the 2,310 listed companies was 630,610 RMB (Gao 2013: 150153). The three highest-paid executives had an average annual salary of $14,583,000$ RMB. In comparison, the average annual wage of employed persons in state-owned units ${ }^{5}$ in China was 47,593 RMB (NBS 2013: 133). This means that business executives in listed companies, on average, took home 13 times more than the average salary in urban units. In the case of the highest-paid executives, they earned 310 times more than the average salary. In the banking sector, the average annual executive pay was 2,235,000 RMB, which equalled 47 times the average pay. The highest-paid drew an annual salary of 7,013,000 RMB, which was 147 times the average pay in the sector. Clearly, income inequalities had widened dramatically in China, almost approaching Western levels.

For many top managers in SOEs, pay is not made public. This is especially the case if the executives are on the payroll of the unlisted mother company, which is not required to report on executive salaries. It is safe to assume that their executive remuneration would not be lower than the salaries enjoyed by the CEOs of the listed companies.

In comparison, high-level officials only enjoy a fraction of the nominal income of the SOE executives. According to the latest available wage table (2006), salaries for civil servants range between 7,560 RMB a year for the lowest-paid office worker (banshiyuan) and 84,240 RMB a year for the President. At the vice-ministerial level, the rank of most central company executives, salaries range between 38,688 RMB and $52,056 \mathrm{RMB}$ a year. At the ministerial/provincial governor level (buji), salaries range between 48,840 RMB and 64,680 RMB a year (Brødsgaard and Gang 2009). In addition, there is a year-end bonus, which at least equals one month's pay, and there are also considerable monetary subsidies as well as huge non-monetary benefits. These salaries have been adjusted several times since the latest wage table was published. Exact numbers for current salaries are not available, but it is a safe assumption that they do not exceed 200,000 RMB a year, including the bonus, for a ministerial-level position.

These differences have caused debate in China and already in the fall of 2014, the Politbureau decided to place a cap of $600,000 \mathrm{RMB}$ a year on executives' annual salaries (China Radio Network 2014; China Daily 2014). The decision would be implemented in companies and financial institutions in monopoly sectors of the economy. However, it was unclear whether exceptions would be tolerated in companies that are exposed to market competition. 
It is an intriguing fact that these measures were introduced without much protest from the affected business leaders. The measures also did not seem to create obstacles for the rotation system. Several explanations can be offered why widespread protest did not occur. First of all, salaries are only one part of the remuneration package of Chinese SOE executives. Various benefits, such as free housing, free car with driver, etc., were not affected. Moreover, SOE leaders kept their administrative ranking, and in a ranking-stratified society, such as the Chinese, this is of great importance and is associated with significant social prestige. Finally, even though some business executives may resent a salary reduction in case of transfer from a business position to a Party or government position, they have no choice but to accept the authority of the Party's Central Organisation Department in cases of cadre rotation. The Party is in charge, and already when executives are selected for training courses abroad, the Party authorities indicate that they may soon be selected for a future Party or government job. On the part of business executives, a transfer is attractive, as it indicates further promotion in the ranking system and thereby, a possibility of postponing retirement. Executives at vice-ministerial rank must retire at the age of 60 , whereas officials at ministerial level can continue to work until they are 65 . In the case of membership of the elite Politburo, the rule of ' 68 down and 67 up' applies, which means that Politburo members can be re-elected to a new five-year term if they are below the age of 68 when a Party congress forms a new Politburo.

The CCP is dependent on recruiting capable leaders and therefore pay much attention to groom promising business leaders. They have many advantages seen from the perspective of the Party authorities. They manage large companies with huge revenues and often hundreds of thousands of employees. Many of the centrally managed enterprises are also active on the global market and their executives earn experiences and competencies, which the Party is eager to tap into.

Looking at CELP data, we can observe that the average age of cadres who are promoted from a SOE executive position to a leading Party or government position were 53.35 years of age at their first political promotion (see Appendix 1). In addition, the data shows that at the time they were moved to their first Party or government position, more than 70 per cent of the cadres were between $49-54$ years old. This might imply that the Central Organisation Department has very clear age and experience selection criteria for the promotion of business executives to Party and government jobs. It also goes to show that the promotion to a Party or government job is their final stop before retiring. 
China is not the only country in which there is a revolving door between business and the political world. In France, members of the civil service elite are often appointed to one of the country's top business positions after having spent a decade or so working for the state (Brødsgaard 2012a). In Japan, the term amakudari denotes the practice of senior officials taking up positions in business after having retired from government office. Nevertheless, these are job changes from government to business and rarely from business to government. The USA is the only major country where there are truly revolving doors between business and politics. In contrast to the Chinese case, it does not take place in a systematic way managed and controlled by a ruling political party. Also, in the Chinese case membership of the Chinese Communist Party is the precondition for being part of the rotation system, whereas individual competencies rather than party affiliation often seem to be decisive in the USA.

This is not to say that individual competencies and abilities of Chinese super managers are not important. They undergo constant training and are annually evaluated by their staff as well as the Party's personnel system. As the CELP shows, the Party also does not hesitate to send them on training courses abroad. The result is the development of a highly capable elite stratum that the Party considers an extremely important recruitment basis for future leaders of China.

China also has large privately-owned enterprises. However, they are not integrated into the power system, as is the case for SOEs. Most of them are small compared to SOEs, and they operate in sectors that are not considered strategic. Even Alibaba, Tencent and Huawei are small compared to the centrally managed enterprises. Among China's 30 largest enterprises, there are only three that are privately owned. Even though private entrepreneurs such as Alibaba's Jack Ma and Tencent's Pony Ma are Party members, they are not considered Party cadres and are not part of the nomenklatura system. Business leaders such as Jack Ma and Pony Ma are rich and would classify as super managers in Piketty's view. However, they are not integrated into the power system, as is the case of SOE leaders, although the Party keeps an eye on their activities in order to prevent them from developing an alternative political and economic power base. The 2021 crackdown on big tech companies and the private education sector serves as a reminder of these fundamental structural qualities of the Chinese system (SCMP 2021). Social stability and Party control of strategic pillars and resources (including data) in the economy always run prior to private capital interests and 
the rule of law. This implies that entire markets and billions in investments can be lost overnight, if the Party deems that to be the right course of action. The CCP is increasingly demanding all enterprises to directly support political goals, and the CCP is actively embedding itself into enterprise management. This particular type of Party-led state capitalist model is argued in the literature to be unique and different from both the developmental state and other state capitalist economies (Blanchette 2020; Pearson 2015; Pearson, Rithmire and Tsai 2021).

In short, in spite of much hype about Chinese entrepreneurs and new privately-owned startups, China is still a Party-led state capitalist country, and the current trend is a more state-controlled economy, not less. The private sector and private entrepreneurs are not part of the iron triangle and therefore not an essential part of the Chinese power system.

\section{Conclusion}

The Chinese economy is dominated by a number of large SOEs. Business executives who are highly educated and trained head them. As the CELP shows, such training often takes place at tailor-made training programs abroad. Chinese business executives are part of the central nomenklatura system managed by the Chinese Communist Party. An important part of the nomenklatura system is cadre rotation, not only within the Party and government system but also between business and Party/government and vice versa. In this way, the CCP maintains an iron triangle of Party-government-business relations, which forms the heart of the power system. The CELP provides a window into this system. It shows that in addition to economic performance and political connections, management skills acquired through training and exposure to foreign business and management practices are important factors in determining an individual's chances of promotion. As a result of the rotation system, Chinese business leaders are quasi officials (zhun guan). They possess administrative ranking and enjoy high salaries and are in fact part of the country's political elite.

KJELD ERIK BRØDGAARD is Professor of China Studies at the Department of International Economics, Government and Business, CBS. His current research covers state-Party-business relations; the nomenklatura system and cadre management in the CCP; Chinese business groups; and Chinese economic thinking and development. Email: keb.egb@cbs.dk. 
KASPER INGEMAN BECK is Postdoctoral Researcher at the Department of International Economics, Government and Business, CBS, and is affiliated with the Sino-Danish Center for Education and Research, University of Chinese Academy of Sciences. His current research covers Chinese state-owned enterprise reforms and governance; state-owned capital funds; and state-Party-business relations. Email: kib.egb@cbs.dk

\section{NOTES}

1. As was emphasised at the Third Plenum of the 19th Central Committee in February 2018, 'Party, government, military, the people, and education, the East, the West, the South, the North, and the Center, the Party is the leader of everything' (CCP 2018).

2. The nomenklatura system can be defined as 'a list containing those leading officials directly appointed by the Party as well as those officials about whom recommendations for appointment, release or transfer may be made by other bodies, but which require the Party's approval'. The central nomenklatura list is a list of those leading positions the Central Organisation Department manages on behalf of the Central Committee. Appointment to these positions is either directly selected by the Party or subject to Party approval, see Brødsgaard (2012b). For an example of a centrally managed nomenklatura list, see Burns (1994).

3. In addition, all 31 provinces and 336 selected cities have their own SASACs. Local SASACs answer directly to their province- or city-level governments but are subject to nationwide standards for supervision and management set by the State Council and the central SASAC. Not all cities and relatively few counties have established a SASAC.

4. In 2002, this practice was abandoned when Chen Xi, member of the Politburo and minister of the Central Organisation Department, was appointed president of the Central Party School.

5. 'State-owned units' statistically include both SOEs and other (non-enterprise) public institutions such as public service units (shiye danwei).

\section{REFERENCES}

Blanchette, Jude. 2020. 'From "China Inc." to "CCP Inc.": A New Paradigm for Chinese State Capitalism'. China Leadership Monitor 66 (Winter 2020): 1-13.

Brødsgaard, Kjeld Erik 2012a. 'Cadre and Personnel Management in the CPC'. China: An International Journal 10 (2): 69-83.

Brødsgaard, Kjeld Erik 2012b. 'Politics and Business Group Formation in China: The Party in Control?' The China Quarterly 211 (September): 624-648. https://doi.org/10.1017/s0305741012000811.

Brødsgaard, Kjeld Erik, and Chen Gang 2009. 'China's Attempt to Professionalize its Civil Service'. EAI Background Brief 94.

Burns, John P. 1994. 'Strengthening Central Party Control of Leadership 
Selection: The 1990 Nomenklatura'. The China Quarterly 138 (June): 458-491. https://doi.org/10.1017/s0305741000035840.

CCP 2018. Zhonggong zhongyang guanyu shenhua dang he guojia jigou gaige de jueding - 2018 nian 2 yue 28 ri Zhongguo gongchandang di shijiu zhongyang weiyuanhui di san ci quanti huiyi tongguo (Decision of the Central Committee on Deepening Reform of Party and State Institutions - Adopted at the Third Plenary Session of the 19th Central Committee of the Communist Party of China on 28 February 2018). Beijing: Xinhua. Accessed 28 September 2021, http://www. xinhuanet.com/politics/2018-03/04/c_1122485476.htm.

Chen, Jay Chih-Jou 2006. 'Elite Mobility in Post-Reform Rural China'. Issues and Studies 42 (2): 53-83.

China Daily 2014. 'Pay cuts approved for SOEs'. China Daily August 30-31.

China Radio Network 2014. 'Yangqi gaoguan xinchou tiaozheng caoan: xiaojian 70\% nian xin bu neng chao 60 wan' (Draft for Regulating the Salary of Executives of Central Enterprises: Reducing by 70 per cent, Yearly Salary can not Exceed 600,000). Zhongguo guangbo wang (China Radio Network). Accessed 28 September 2021, http:/ / china. cnr.cn/xwwgf/201408/t20140827_516310751.shtml.

Deng, Xiaoping 1983. 'Dang he guojia lingdao zhidu de gaige' (Reform of the Leadership System of Party and State). In Xiaoping Deng Deng Xiaoping wenxuan 1975-1982 (Selected works by Deng Xiaoping 1975-1992). Shanghai: Renmin chubanshe.

FBIS 1986. 'A Speech of Deng Xiaoping for Restricted Use Only'. Foreign Broadcast Information Service Daily Reports FBIS-CHI-86-117 (June 18): W1-2.

Gao, Minghua (2013). Zhongguo shangshi gongzi gaoguan xinchou zhishu baogao (Index of China's Listed Companies: Report on Executive Compensation, 2013). Beijing: Jingji kexue chubanshe.

Landry, Pierre F., Xiaobo Lü, and Haiyan Duan 2014. Does Performance Matter? Evaluating Political Selection Along the Chinese Administrative Ladder. Paper presented at the 'APSA 2014 Annual Meeting', Washington DC, 2 August 2014. Accessed 29 September 2021, https:// papers.ssrn.com/sol3/papers.cfm?abstract_id=2452482.

Lee, Charlotte 2015. Party Adaption and Elite Training in China. Cambridge: Cambridge University Press.

Lenin, Vladimir Ilyich 1973. What is to be Done? Burning Questions of Our Movement. Beijing: Foreign Languages Press (originally published 1902). 
Leutert, Wendy 2018. 'The Political Mobility of China's Central StateOwned Enterprise Leaders'. The China Quarterly 233 (March): 1-21. https:// doi.org/10.1017/s0305741017001412.

Li, Hongbin, and Li-An Zhou 2005. 'Political Turnover and Economic Performance: The Incentive Role of Personnel Control in China'. Journal of Public Economics 89: 1743-1762. https:// doi.org/10.1016/j. jpubeco.2004.06.009.

NBS 2013. Zhongguo tongji nianjian 2013 (China Statistical Yearbook 2018). Beijing: Zhongguo tongii chubanshe.

NBS 2018. Zhongguo tongji nianjian 2018 (China Statistical Yearbook 2018). Beijing: Zhongguo tongji chubanshe.

NPC 1993. 'Guojia gongwuyuan zanxing tiaoli' (Provisional Civil Service Regulations). In Renshi gongzuo wenjian xuanji 16juan (Selection of personnel working documents vol. 16). Beijing: Zhongguo renshi chubanshe, pp. 5-21.

Pearson, Margaret 2015. 'State-owned Business and Party-State Regulation in China's Modern Political Economy'. In Barry Naughton and Kellee Sing Tsai (eds.), State Capitalism, Institutional Adaptation, and the Chinese Miracle. Cambridge: Cambridge University Press, pp. 27-45.

Pearson, Margaret, Meg Rithmire, and KelleeSing Tsai 2021. 'Party-State Capitalism in China'. Current History September 2021: 207-213.

Pieke, Frank 2009. The Good Communist: Elite Training and State Building in Today's China. Cambridge: Cambridge University Press.

Piketty, Thomas 2014. Capital in the Twenty-First Century. Cambridge, MA: The Belknap Press of Harvard University Press.

SASAC 2017. SASAC Statistical Yearbook 2017. Beijing: The State-owned Assets Supervision and Administration Commission of the State Council (SASAC).

SCMP 2021. 'China's Big Tech crackdown: Will Beijing's Efforts Kill the Country's Most Vibrant Economic Sector?' South China Morning Post 31 July 2021. Accessed 28 September 2021, https:/ / www.scmp. com/tech/big-tech/article/3143241/chinas-big-tech-crackdownwill-beijings-efforts-kill-countrys-most.

Shambaugh, David 2016. China's Future. Cambridge: Polity Books.

Shih, Victor, Christopher Adolph, and Mingxing Liu 2012. 'Getting Ahead in the Communist Party: Explaining the Advancement of Central Committee Members in China'. American Political Science Review 106 (1): 166-187. https:/ / doi.org/10.1017/ s0003055411000566.

Sina 2009. 'Yangqi gao guan xinchou paihang bang' (Central SOE Executive Salary Ranking). Xinlang shangpin (Sina Shangpin). Accessed 
28 September 2021, http://style.sina.com.cn/news/2009-0415/094238908.shtml.

Sohu 2010. 'Caizheng bu cha yangqi gao guan qunian xinchou cheng buyi chaoguo yuangong 20 bei' (The Ministry of Finance Checked the Salary of the Executives of Central Enterprises Last Year and Said it Should not Exceed 20 Times the Employees). Yangcheng wanbao (Yangcheng Evening News). Accessed 28 September 2021, https:/ / business.sohu.com/20101206/n278127808.shtml.

Yang, Ruilong, Yuan Wang, and Huihua Nie 2013. 'Zhun guanyuan de jinsheng jizhi: Laizi zhongguo yangqi de zhengju' (The Political Promotion for Quasi-Government Officers: Evidence from Central State-Owned Enterprises in China). Management World 3: 23-33.

Zhang, Jun, Qi Zhang, and Zhikuo Liu 2017. 'The Political Logic of Partial Reform of China's State-Owned Enterprises'. Asian Survey 57 (3): 395-415.

\section{APPENDIX}

\begin{tabular}{|l|l|l|}
\hline \multicolumn{1}{|c|}{ Name } & $\begin{array}{c}\text { CELP year } \\
\text { position } \\
\text { (year of CELP } \\
\text { participation) }\end{array}$ & \multicolumn{1}{c|}{ Current position* (year) } \\
\hline $\begin{array}{l}\text { FAN Dazhi } \\
\text { Born in } \\
1964\end{array}$ & $\begin{array}{l}\text { Senior Vice } \\
\text { President, Bank } \\
\text { of China (2017) }\end{array}$ & $\begin{array}{l}\text { Chief Inspector of the Discipline } \\
\text { Inspection and Supervision Office } \\
\text { of CCP Central Commission for } \\
\text { Discipline Inspection (CCDI) and } \\
\text { member of the CSRC Party Com- } \\
\text { mittee (2019-). } \\
\text { (Age at first political/government } \\
\text { job: 55) }\end{array}$ \\
\hline $\begin{array}{l}\text { SHI Dai } \\
\text { Born in } \\
1967\end{array}$ & $\begin{array}{l}\text { Senior Vice } \\
\text { President, } \\
\text { Sinochem (2017) }\end{array}$ & $\begin{array}{l}\text { Member of the Standing Commit- } \\
\text { tee of the CCP Party Committee } \\
\text { of Ningxia Autonomous Region } \\
\text { (2019-), } \\
\text { Director of the Ningxia Autono- } \\
\text { mous Region Organization Depart- } \\
\text { ment (2019-), } \\
\text { Vice Chairman (concurrently) of }\end{array}$ \\
\hline
\end{tabular}




\begin{tabular}{|c|c|c|}
\hline & & $\begin{array}{l}\text { the All-China Women's Federation } \\
\text { (2018-) } \\
\text { (Age at first political/government } \\
\text { position: } 50 \text { ) }\end{array}$ \\
\hline $\begin{array}{l}\text { DING } \\
\text { Xuedong } \\
\text { Born in } \\
1960\end{array}$ & $\begin{array}{l}\text { Chairman \& } \\
\text { CEO, China } \\
\text { Investment Cor- } \\
\text { poration (2015) }\end{array}$ & $\begin{array}{l}\text { Deputy Secretary-General of the } \\
\text { State Council (2017-). Full member } \\
\text { of the 19th CCP Central Committee } \\
\text { (Age at first political/government } \\
\text { position: 57) }\end{array}$ \\
\hline $\begin{array}{l}\text { WU } \\
\text { Yanhua } \\
\text { Born in } \\
1962\end{array}$ & $\begin{array}{l}\text { Executive Vice } \\
\text { President, China } \\
\text { Aerospace Sci- } \\
\text { ence \& Technol- } \\
\text { ogy Corporation } \\
(2014)\end{array}$ & $\begin{array}{l}\text { Deputy Director-General \& Mem- } \\
\text { ber of Party Leadership Group, } \\
\text { State Administration for Science, } \\
\text { Technology and Industry for } \\
\text { National Defence \& Deputy } \\
\text { Director-General, China National } \\
\text { Space Administration (2014-) } \\
\text { (Age at first political/government } \\
\text { position: 52) }\end{array}$ \\
\hline $\begin{array}{l}\text { TANG } \\
\text { Dengjie } \\
\text { Born in } \\
1964\end{array}$ & $\begin{array}{l}\text { President, China } \\
\text { South Industries } \\
\text { Group Corpora- } \\
\text { tion (2012) }\end{array}$ & $\begin{array}{l}\text { Deputy Party Secretary and Vice } \\
\text { Minister, National Development } \\
\text { and Reform Commission (NDRC) } \\
\text { (2020-). } \\
\text { (Age at first political/government } \\
\text { position: } 53 \text { ) }\end{array}$ \\
\hline $\begin{array}{l}\text { CAO } \\
\text { Jianguo } \\
\text { Born in } \\
1963\end{array}$ & $\begin{array}{l}\text { Vice President, } \\
\text { China Aero- } \\
\text { space Science } \\
\text { and Industry } \\
\text { Corporation } \\
(2012)\end{array}$ & $\begin{array}{l}\text { Currently Chairman and Party } \\
\text { Secretary of China Aerospace } \\
\text { Science and Industry Corporation. } \\
\text { Alternate member of the 19th CCP } \\
\text { Central Committee (2017-) } \\
\text { (Age at first political/government } \\
\text { position: 54) }\end{array}$ \\
\hline $\begin{array}{l}\text { FAN } \\
\text { Youshan } \\
\text { Born in } \\
1963\end{array}$ & \begin{tabular}{|l} 
Party Secretary \\
\& Senior Vice \\
President, China \\
Electronics Tech- \\
nology Group \\
Corporation \\
(2011)
\end{tabular} & $\begin{array}{l}\text { Vice Chairman \& Deputy Party } \\
\text { Secretary, All-China Federation of } \\
\text { Industry \& Commerce (2016-) } \\
\text { (Age at first political/government } \\
\text { position: 53) }\end{array}$ \\
\hline
\end{tabular}




\begin{tabular}{|c|c|c|}
\hline $\begin{array}{l}\text { GUAN } \\
\text { Qing } \\
\text { Born in } \\
1964\end{array}$ & $\begin{array}{l}\text { Senior Vice } \\
\text { President, Con- } \\
\text { struction Engi- } \\
\text { neering Corpo- } \\
\text { ration (2010) }\end{array}$ & $\begin{array}{l}\text { Senior Vice President, Construction } \\
\text { Engineering Corporation (2010) } \\
\text { Alternate member of the 19th CCP } \\
\text { Central Committee (2017-2020) } \\
\text { (passed away) } \\
\text { (Age at first political/government } \\
\text { position: 53) }\end{array}$ \\
\hline $\begin{array}{l}\text { LIU } \\
\text { Liehong } \\
\text { Born in } \\
1968\end{array}$ & $\begin{array}{l}\text { President, China } \\
\text { Electronics } \\
\text { Corporation } \\
(2010)\end{array}$ & $\begin{array}{l}\text { Member of the Party Leadership } \\
\text { Group and Deputy Minister of the } \\
\text { Ministry of Industry and Informa- } \\
\text { tion Technology (MIIT) (2020-) } \\
\text { (Age at first political/government } \\
\text { position: 50) }\end{array}$ \\
\hline $\begin{array}{l}\text { YUAN } \\
\text { Jiajun } \\
\text { Born in } \\
1962\end{array}$ & $\begin{array}{l}\text { Vice President, } \\
\text { China Aero- } \\
\text { space Science } \\
\text { \& Technology } \\
\text { Corporation } \\
(2010)\end{array}$ & $\begin{array}{l}\text { Party Secretary, Zhejiang Province } \\
\text { (2020-). Alternate member of the } \\
\text { 17th Central Committee and full } \\
\text { member of the 19th Central } \\
\text { Committee. } \\
\text { (Age at first political/government } \\
\text { position: 50) }\end{array}$ \\
\hline $\begin{array}{l}\text { MU } \\
\text { Zhanying } \\
\text { Born in } \\
1955\end{array}$ & $\begin{array}{l}\text { President \& } \\
\text { Party Secretary, } \\
\text { China Nuclear } \\
\text { Engineering } \\
\text { Group Corpora- } \\
\text { tion (2009) }\end{array}$ & $\begin{array}{l}\text { Chairman of the Supervision Com- } \\
\text { mittee, central SASAC (2012-) } \\
\text { (Age at first political/government } \\
\text { position: } 57 \text { ) }\end{array}$ \\
\hline $\begin{array}{l}\text { WANG } \\
\text { Zhigang } \\
\text { Born in } \\
1957\end{array}$ & $\begin{array}{l}\text { President \& Vice } \\
\text { Party Secretary, } \\
\text { China Electron- } \\
\text { ics Technology } \\
\text { Group Corpora- } \\
\text { tion (2009) } \\
\end{array}$ & $\begin{array}{l}\text { Minister \& Party Secretary, Ministry } \\
\text { of Science and Technology (2018-). } \\
\text { Full member of the 18th and 19th } \\
\text { CCP Central Committee (from 2017) } \\
\text { (Age at first political/government } \\
\text { position: 56) }\end{array}$ \\
\hline $\begin{array}{l}\text { GONG } \\
\text { Jingkun } \\
\text { Born in } \\
1958\end{array}$ & $\begin{array}{l}\text { Chairman \& } \\
\text { Party Secretary, } \\
\text { Harbin Electric } \\
\text { Corporation } \\
(2009) \\
\end{array}$ & $\begin{array}{l}\text { Vice Chairman, People's Political } \\
\text { Consultative Conference, Heilongji- } \\
\text { ang Province (2015-) } \\
\text { (Age at first political/government } \\
\text { position: 57) }\end{array}$ \\
\hline
\end{tabular}




\begin{tabular}{|c|c|c|}
\hline $\begin{array}{l}\text { XU } \\
\text { Zhanbin } \\
\text { Born in } \\
1964\end{array}$ & $\begin{array}{l}\text { Senior Vice } \\
\text { President \& } \\
\text { Chief Accoun- } \\
\text { tant, Aviation } \\
\text { Industry Corpo- } \\
\text { ration of China } \\
\text { (2007 }\end{array}$ & $\begin{array}{l}\text { Deputy Director General \& Member } \\
\text { of Party } \\
\text { Leadership Group, State Admin- } \\
\text { istration for Science, Technology } \\
\text { and Industry for National Defence } \\
\text { (2014-) } \\
\text { (Age at first political/government } \\
\text { position: } 50 \text { ) }\end{array}$ \\
\hline $\begin{array}{l}\text { WANG } \\
\text { Huisheng } \\
\text { Born in } \\
1956\end{array}$ & $\begin{array}{l}\text { Chairman \& } \\
\text { Party Secretary, } \\
\text { State Devel- } \\
\text { opment and } \\
\text { Investment Cor- } \\
\text { poration (2006) }\end{array}$ & $\begin{array}{l}\text { Member of the CCP Central } \\
\text { Commission for Discipline } \\
\text { Inspection (2017-) } \\
\text { (Age at first political/government } \\
\text { position: } 53 \text { ) }\end{array}$ \\
\hline $\begin{array}{l}\text { ZHANG } \\
\text { Guoqing } \\
\text { Born in } \\
1964\end{array}$ & $\begin{array}{l}\text { Senior Vice } \\
\text { President, China } \\
\text { North Indus- } \\
\text { tries Corpora- } \\
\text { tion (2006) }\end{array}$ & $\begin{array}{l}\text { Party Secretary, Liaoning Province } \\
\text { (2020-) Alternate member of the } \\
\text { 17th and full member of the 18th } \\
\text { and 19th Central Committee Full } \\
\text { Member of Central Committee. } \\
\text { (Age at first political/government } \\
\text { position: 49) }\end{array}$ \\
\hline $\begin{array}{l}\text { ZHANG } \\
\text { Qingwei } \\
\text { Born in } \\
1961\end{array}$ & $\begin{array}{l}\text { President, China } \\
\text { Aerospace Sci- } \\
\text { ence \& Technol- } \\
\text { ogy Corporation } \\
(2006)\end{array}$ & $\begin{array}{l}\text { Party Secretary, Heilongjiang } \\
\text { Province (2017-). Full member of } \\
\text { the 16th, 17th, 18th and 19th CCP } \\
\text { Central Committee. } \\
\text { (Age at first political/government } \\
\text { position: } 52 \text { ) }\end{array}$ \\
\hline $\begin{array}{l}\text { XIAO } \\
\text { Yaqing } \\
\text { Born in } \\
1959\end{array}$ & $\begin{array}{l}\text { President, } \\
\text { Aluminium } \\
\text { Corporation of } \\
\text { China (2006) }\end{array}$ & $\begin{array}{l}\text { Minister and Party Secretary, Min- } \\
\text { istry of Industry and Information } \\
\text { Technology (MIIT) (2020-). Alter- } \\
\text { nate member of and member of the } \\
\text { 17th and full member of the 19th } \\
\text { CCP Central Committee. Member } \\
\text { of the 18th CCP Central Disci- } \\
\text { plinary Inspection Commission. } \\
\text { (Age at first political/government } \\
\text { position: 50) }\end{array}$ \\
\hline
\end{tabular}




\begin{tabular}{|l|l|l|}
\hline $\begin{array}{l}\text { LI Dang } \\
\text { Born in } \\
1956\end{array}$ & $\begin{array}{l}\text { President, China } \\
\text { General Tech- } \\
\text { nology Group } \\
(2005)\end{array}$ & $\begin{array}{l}\text { Vice Chairwoman, the Central } \\
\text { Committee of China Democratic } \\
\text { National Construction Association; } \\
\text { Member of the Standing Committee } \\
\text { and the Foreign Affairs Committee, } \\
\text { Chinese People's Political Consulta- } \\
\text { tive Conference (CPPCC) (2018-). } \\
\text { (Age at first political/government } \\
\text { position: 62) }\end{array}$ \\
\hline $\begin{array}{l}\text { MA } \\
\text { Bingrui } \\
1959\end{array}$ & $\begin{array}{l}\text { Senior Vice } \\
\text { President, China } \\
\text { Aerospace Sci- } \\
\text { ence \& Technol- } \\
\text { ogy Corporation } \\
\text { (2005) }\end{array}$ & $\begin{array}{l}\text { Governor, Guangdong Province } \\
\text { (2017-). Full member of the 19th } \\
\text { and 19th CCP Central Committee. } \\
\text { (Age at first political/government } \\
\text { position: 54) }\end{array}$ \\
\hline
\end{tabular}

Notes: *there might be previous Party or government positions not mentioned in the table. The table shows only the current position(s) as of July 2021. 